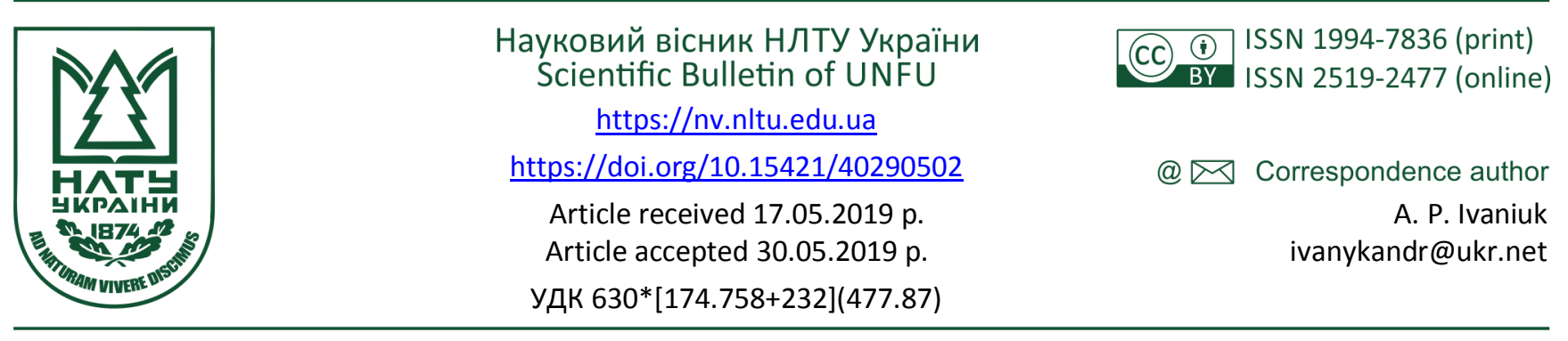

М. М. Гузь' ${ }^{1}$ А. П. Іванюк ${ }^{1}$ М. М. Король ${ }^{1}$, Т. В. Феннич ${ }^{2}$

${ }^{I}$ Начіональний лісотехнічний університет Украӥни, м. Львів, Украӥна

${ }_{2}^{2}$ Регіональна філія "Львівська залізниия", м. Львів, Украӥна

\title{
ОСОБЛИВОСТІ РОСТУ КЕДРА АТЛАСЬКОГО (CEDRUS ATLANTICA (ENDL.) MANETTI EX CARRIËRE) У ЛICOВИХ КУЛЬТУРАХ ЗАКАРПАТТЯ
}

\begin{abstract}
Наведено коротку характеристику кедра атласького та досліджено історію створення насаджень інтродуцента на території держлісфонду державного підприємства "Мукачівське лісомисливське господарство". Встановлено, що оптимальними умовами для культивування кедра атласького в лісових культурах є свіжі й вологі грудові типи лісорослинних умов $\left(\mathrm{D}_{2-3}\right)$ у передгірській частині Закарпаття до висоти 600 м н.р.м. Визначено показники продуктивності насаджень досліджуваної породи. Встановлено, що в дібровних типах лісорослинних умов кедр атласький на Закарпатті перевершує таксаційні показники аборигенних деревних порід. Порівняльна оцінка лісівничо-таксаційних показників, у розрізі кожної зростаючої породи на досліджуваній ділянці, свідчить, що кедр атласький характеризується кращими показниками розвитку. Запас досліджуваного деревостану, де склад є таким - 8Кда1Яц1См+Клг+Лпд, у 40 річному віці становить 293 м 3 /га і середній приріст за запасом відповідно - 7,1 м 3 га рік. Встановлено, що мішані насадження кедра атласького за середньою висотою та діаметром достовірно вищі, порівняно із чистими деревостанами в однакових грунтово-кліматичних умовах Закарпаття. Розпочаті дослідження мають на меті встановлення перспектив використання породи у лісокультурному виробництві регіону, визначення ступеня натуралізації виду та агресивності його поведінки щодо автохтонних деревних видів рослин у корінних типах лісу.

Ключові слова: кедр атласький; ріст; інтродуцент; природне поновлення; лісові культури.
\end{abstract}

Вступ. Проблема стійкості лісових насаджень, через зміну клімату займає вагоме місце в лісівничій науці, а особливо у виробництві. Зміна клімату породжує нові виклики людству у зміні природних екосистем, зокрема лісових. Це супроводжується різними пошкодженнями деревостанів аборигенних видів, яке на початках виникає із зміною температури та вологості (водного режиму). Сьогодні лісівники європейських країн шукають альтернативні деревні породи, які можуть замінити нестійкі смерекові та соснові насадження. Це питання можна вирішувати завдяки формуванню лісів майбутнього 3 орієнтацією на корінні породи із впровадженням інтродуцентів, але необхідно врахувати їхню біологічну стійкість в умовах зростання. Цього напряму стосується багато досліджень і його вирішення можливе тільки за умови комплексного підходу щодо запровадження інтродуцентів із врахуванням оптимального співвідношення з автохтонними видами (Guz, Ivaniuk \& Fennich, 2010; Kuznetcov, 1984; Loginov, 1988; Smagliuk, 1974; Yatsyk, Brodovych \& Havrusevych, 1997; Bariteau \& Vauthier, 2011; Brunetti et al., 2001; Courbet et al., 2012; Dörken \& Stützel, 2009).

Виходячи із парадигми довгожиттєвості деревних порід, необхідно добре обдумати і зіставити екологічні та економічні ризики, а також їхні біологічні властивос- ті. Оскільки зміна клімату відбувається досить швидко, тому для природного пристосування локальних популяцій необхідно більше часу, з генетичної сторони можливо через декілька поколінь. Введення нових лісових порід (інтродуцентів), які є толерантними для відповідного типу лісорослинних умов і стабілізують розладнані корінні деревостани, а також підвищать генетичну різноманітність та стійкість, потребує знань та володіння досвідом щодо акліматизації та росту інтродуцентів у запропонованих регіонах.

Закарпаття - один з найбільш перспективних регіонів України для інтродукції деревних і чагарникових порід. Сучасні кліматичні умови рівнинної і передгірної частини Закарпаття сприятливі для вирощування в лісових і паркових насадженнях багатьох видів рослин, відсутніх у природній флорі.

Інтродукція деревних та чагарникових видів розпочалась у Закарпатті досить давно. За даними С. С. Фодора (1956 р.), виноград, горіх грецький, каштан їстівний та ін. були завезені в Закарпаття з Балканського півострова ще в XI-XII ст. (Fodor, 1956). Першими з неплодових деревних порід були інтродуковані платани в 1610 р. Пізніше в Закарпатті появився гіркокаштан кінський звичайний, акація біла, тополя пірамідальна. Найбільш інтенсивне впровадження екзотів у сади, ар-

\section{Інформація про авторів:}

Гузь Микола Михайлович, д-р с.-г. наук, професор, завідувач кафедри лісових культур. Email: mguz@ukr.net Іванюк Андрій Петрович, канд. с.-г. наук, доцент, кафедра лісових культур і лісової селекції. Email: ivanykandr@ukr.net Король Микола Михайлович, канд. с.-г. наук, доцент, кафедра лісової таксації та лісовпорядкування. Email: nikkorol@ukr.net Феннич Тарас Васильович, інженер. Email: taraskin_ne@i.ua

Цитування за ДСтУ: Гузь М. М., Іванюк А. П., Король М. М., Феннич Т. В. Особливості росту кедра атласького (Cedrus Atlantica (Endl.) Manetti ex Carrière) у лісових культурах Закарпаття. Науковий вісник Нлту України. 2019, т. 29, № 5. С. 12-16.

Citation APA: Huz, M. M., Ivaniuk, A. P., Korol, M. M., \& Fennuch, T. V. (2019). Some peculiarities of atlas cedar (Cedrus Atlantica (Endl.) Manetti ex Carrière) growth in forest plantations of Transcarpathia. Scientific Bulletin of UNFU, 29(5), 12-16. https://doi.org/10.15421/40290502 
боретуми, парки розпочалось наприкінці XIX ст. і на початку XX ст. У цей період були створені в містах і селах Закарпатської обл. цінні дендрологічні насадження, зокрема: Мукачівський міський парк (1925р.), арборетум у м. Ужгороді, заснований в 1895 р. Лаудоном, Велико-Березнянський парк (1906 р.), парк санаторію "Карпати" (1886-1912рр.), Виноградівський міський парк (1880р.), дендрологічні насадження в с. Буштино (1910-1928 pp.) та інші. Насіннєва база цих дендрологічних об'єктів сприяла подальшому поширенню екзотів як у сферу озеленення населених пунктів, так і в лісове господарство (Loginov, 1988; Yatsyk, Brodovych \& Havrusevych, 1997; Yatsyk et al., 1999).

Починаючи з 1951 р., під керівництвом науковців Карпатської ЛНДС П. І. Молоткова, П. С. Каплуновського, В. І. Гніденко почав створюватись дендрарій "Березинка", який знаходиться на території держлісфонду ДП "Мукачівське ЛМГ". Науковці станції виписували насіння з багатьох ботанічних садів, лісових дослідних станцій, дендропарків і випробували близько 2000 видів та форм деревних і кущових порід інтродуцентів (Hnidenko, 1968; Kaplunovskyi \& Fennych, 1998). Сьогодні колекція дендрарію нараховує приблизно 340 видів і форм екзотів, які $є$ насіннєвою і вегетативною базою для їх подальшого поширення. Одночасно вдосконалювалась технологія вирощування садивного матеріалу, створювались на різних висотах натуралістичні ділянки за участю екзотів, дослідно-виробничі культури.

Сьогодні на території держлісфонду ДП "Мукачівське ЛМГ" створено 708,7 га лісових культур за участю інтродуцентів. В основу лісокультурного виробництва на підприємстві взято принцип відтворення на більшості площ корінних високопродуктивних, біологічно стійких, з високими захисними властивостями деревостанів. Перевага при цьому надається мішаним за складом порід культурам, які краще виконують захисні функції і характеризуються вищою біологічною стійкістю та продуктивністю. Надмірне захоплення екзотами за рахунок цінних порід не завжди виправдане під час створення звичайних виробничих культур. Впровадження інтродуцентів доцільне в таких грунтово-кліматичних умовах, де вони забезпечують більший лісівничий ефект, ніж аборигенні породи (Hordiienko et al., 2005; Guz, Ivaniuk \& Fennich, 2010; Smagliuk, 1974; Yatsyk, Brodovych \& Havrusevych, 1997). Одним із таких деревних видів є кедр атласький, інтродукція якого в Закарпатті почалася з 1958 р., одночасно з іншими видами кедра - гімалайським і ліванським. Останні два види в цих умовах виявилися непридатними для лісової інтродукції.

Мета роботи - вивчити особливості росту кедра атласького за лісівничо-таксаційними показниками у чистих і мішаних лісових культурах ДП "Мукачівське ЛМГ".

Матеріал і методи дослідження. Дослідження росту та розвитку кедра атласького, який інтродукований на Закарпатті, здійснювали на основні основних лісівничо-таксаційних показників. Заміри цих показників проводили відповідно до загальноприйнятої методики лісівничо-таксаційних досліджень (Herushynskyi, 1996; Gorshenin \& Buteiko, 1962; Tokar et al., 2016; Gadow, 2001; Pretzsch, 2001). Для порівняння використали матеріали досліджень двох ділянок лісових культур за участю кедра атласького, які зростають на території держлісфонду ДП "Мукачівського ЛМГ". Перша 3 них знаходиться у кв. 40 вид. 10 виробничої лісонасіннєвої станції "Березинка", площею 1,5 га, а друга ділянка безпосередньо на території дендрарію "Березинка" окремою куртиною без присутності супутніх порід, площею 0,02 га.

На першій ділянці лісові культури створені на землях після тривалого землекористування на площі 1,5 га $(250 \times 60$ м) у 1968 р. Рельєф рівнинний. Висота н.р.м. становить 180 м. Ірунти середньосуглинисті з сильно порушеною структурою. Садіння здійснювали під шнур після суцільного обробітку грунту. У перший рік після садіння проводили трьохразовий агротехнічний догляд. Під час створення культур кількість садивних місць становила 7,5 тис. шт., 3 яких 1,6 тис. шт. було висаджено 3-річними сіянцями кедра атласького. Сіянці кедра атласького висадили у змішаних культурах із ялицею білою, ялиною звичайною, липою дрібнолистою, кленом гостролистим. Створюючи ці культури, використали дві схеми змішування порід: перша передбачала змішування 2 рядів кедра атласького 32 рядами ялиці білої, а друга - 2-х рядів кедра атласького з 2 рядами ялини звичайної. Окрім цього, в ряди головних порід вводили супутні породи - липу дрібнолисту та клен гостролистий, чергуванням у рядах з головними породами кожним другим садивним місцем.

Другу ділянку лісових культур створили також методом садіння у 1968 р., де висота н.р.м. становила 200 м, грунти суглинисті, середньої потужності, мало гумусові ущільнені, тип лісорослинних умов - $\mathrm{C}_{2-3}$. Це чиста куртина площею 0,02 га $(10 \times 20$ м). Спостереження за розвитком цього виду на цих ділянках проводили протягом всього періоду, де відповідно отримували результати замірів (4 - заміри за період росту).

Результати дослідження. Рід кедр - Cedrus Trew. нараховує всього чотири види (кедр кіпрський, атласький, ліванський та гімалайський) i $\epsilon$ найменшим родом родини соснових - Pinaceae Lindl. Кедри мають розірваний, дез'юктивний ареал. Це могутні вічнозелені дерева висотою до 50 м. Хвоя цих дерев видоспецифічна, так для кедра атласького досить коротка 1-2 см, а для кедра гімалайського 5-6 см, у пучку їх може бути 3040 шт. (Zaiachuk, 2003; Bariteau \& Vauthier, 2011; Krüssmann, 1983). Верхівки хвоїнок є досить гострими і в поперечному розрізі здебільшого 4-гранні. Епідерміс підтримується товстим шаром епікутикулярного воску, що робить хвою блакитною, особливо в кедра атласького (Cedrus atlantica (Endl.) Manetti ex Carrière). За своїм габітусом розвиваються по-різному. У молодому віціце струнке із пірамідальною кроною, а у старшому - це могутне, із розлогою парасолеподібною кроною дерево 3 рівномірно розміщеними горизонтальними гілками.

Дерева однодомні, мікро- та макростробіли циліндричної форми, які розміщені поодиноко вертикально на охвоєних брахибластах. Шишки яйцеподібні, які спрямовані також вгору і після дозрівання розсипаються (Brunetti et al., 2001; Huber \& Storz, 2014; Mundry, 2000) (рис. 1).

Природне поновлення кедра атласького починає з'являтися в умовах Закарпаття після насіннєвих років. У перший рік під наметом деревостану самосіву проростає до 5000 шт./га (рис. 2). Але внаслідок потужної лісової підстилки, через яку корінці самосіву не здатні проникнути у грунт, до наступного року самосів кедра атласького практично гине. Залишаються тільки пооди- 
нокі екземпляри в більш зволожених мікропониженнях та в місцях із меншим шаром лісової підстилки.
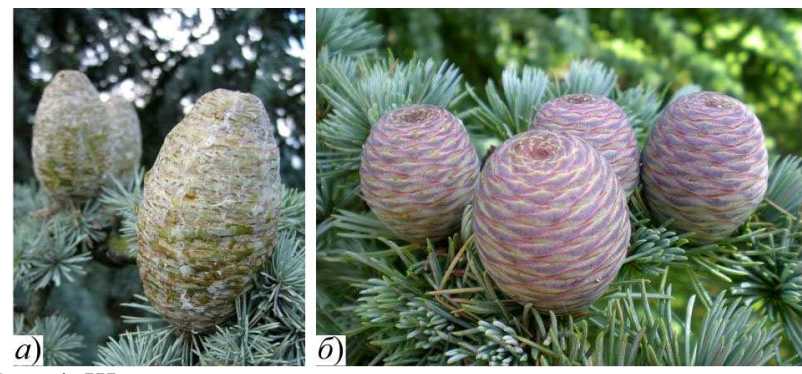

Рис. 1. Шишки кедра атласького

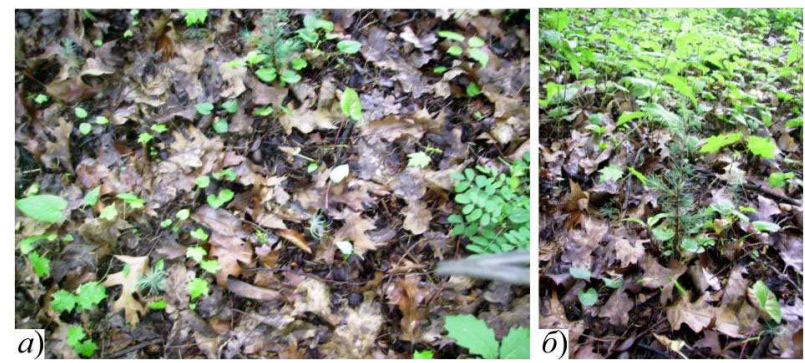

Рис. 2. Природне поновлення кедра атласького

Такі молоді особини самосіву потребують особливого догляду та захисту від конкуренції місцевих деревних порід, насамперед клена гостролистого. Обліковані дані свідчать про високу насіннєву спроможність інтродуцента, але низьку стійкість самосіву в початковому (ювенільному) періоді росту та низьку конкурентоспроможність. Ці особливості потрібно брати до уваги у перші роки формування насадження з участю кедра атласького (Courbet et al., 2012; Muhidin, 2019).

Кедр атласький (Cedrus atlantica (Endl.) Manetti ex Carrière) відносно тіньовитривала деревна порода, яка дуже добре росте в мішаних деревостанах і не інвазійна. Ареал його поширення наведено схематично на рис. 3 за даними (Mundry, 2000).

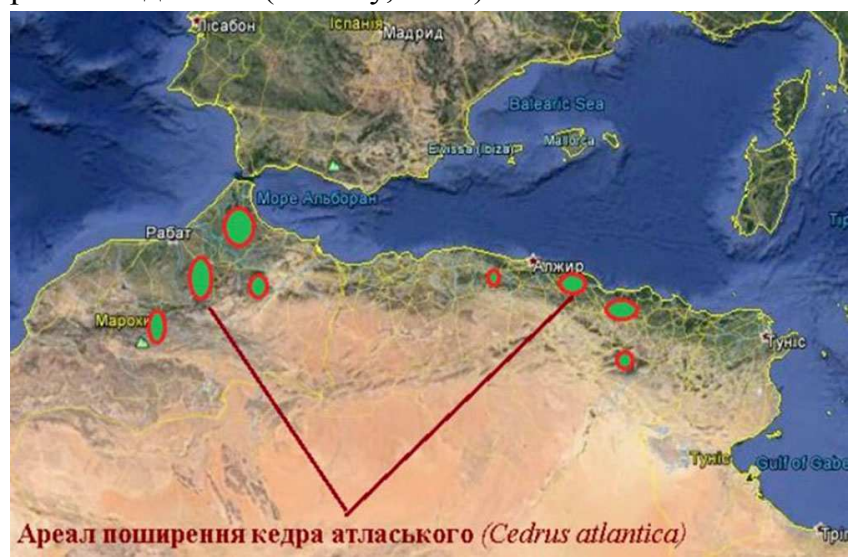

Рис. 3. Ареал поширення кедра атласького Cedrus atlantica (Endl.) Manetti ex Carrière

За літературними даними, площа природного кедра атласького, який зростає у Марокко, сьогодні займає близько 140 тис. га, половині з яких притаманні сильно деградовані лісорослинні умови. В Алжирі, через свою дорогоцінну деревину, цю породу інтенсивно вирубували, тому зараз вона займає тільки 14 тис. га. До Європи кедр атласький потрапив у першій половині XIX ст. як декоративне та паркове дерево. За своїми властивостями - це теплолюбне, посухостійке і морозостійке дерево. Може витримувати низькі температури (до $-28{ }^{\circ} \mathrm{C}$, але не тривалий час, а також високі тепловтрати до $\left.+40{ }^{\circ} \mathrm{C}\right)$. На своїй батьківщині ця порода зростає на висотах від 1600 до 2400 м н.р.м., де кількість опадів становить 900-1500 мм. У природному ареалі зростає кедр атласький зростає віком до 700 років, висота окремих дерев при цьому може становити до 50 м, а діаметр від 150 см, приріст запасу деревини при цьому становить 8,3 $\mathrm{m}^{3} /$ га (Muhidin, 2019).

Продуктивність інтродукованого кедра атласького у Європі залежить від умов зростання. Так, в Угорщині, за даними (Brunetti et al., 2001; Krüssmann, 1983), у посушливих лісорослинних умовах запас у віці 20, 30 i 36 років відповідно становив 248, 529 та 545 м $^{3} / г а$. Площа поперечного перерізу при цьому становить 30,0; 49,$6 ; 50,2$ м²/га. У Франції загальний запас у віці 130 років становить понад $883 \mathrm{~m}^{3} /$ га (Huber \& Storz, 2014; Muhidin, 2019).

Наші дослідження на Закарпатті свідчить про те, що мішані насадження кедра атласького за середньою висотою та діаметром достовірно вищі, порівняно із чистими деревостанами, хоча грунтові та кліматичні умови однакові, і цю закономірність добре ілюстровано на рис. 4. Оскільки за своїми біологічними властивостями кедр атласький у молодому віці, до 20 років, характеризується повільним ростом як за висотою, так і за діаметром, тому істотної різниці між чистими та мішаними насадженнями до цього періоду не спостерігали.
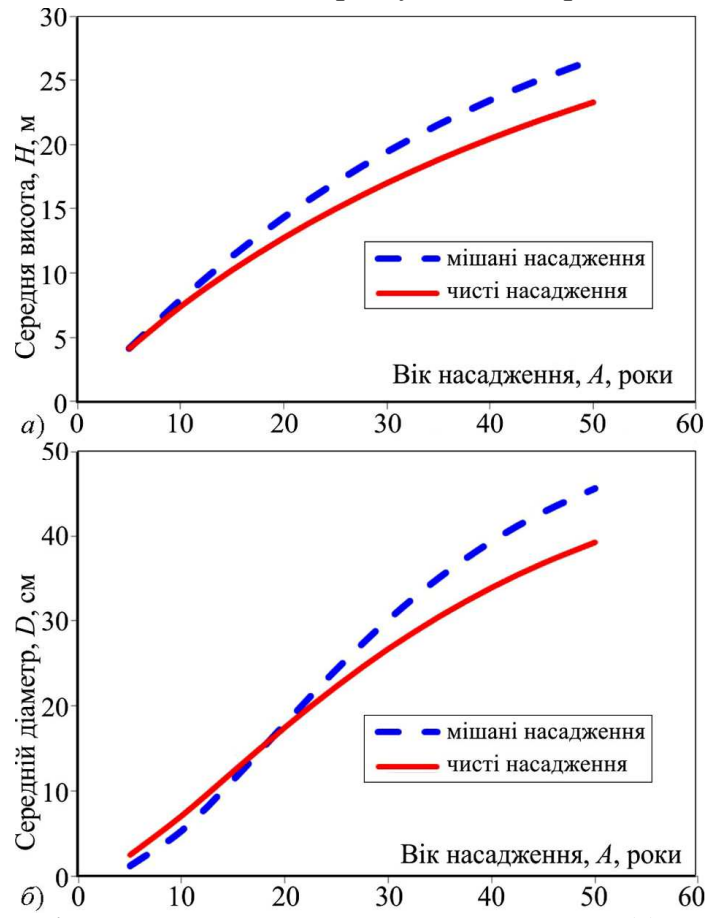

Рис. 4. Ріст кедра атласького за середньою висотою $(a)$ та ріст кедра атласького за середнім діаметром (б)

Характерний вплив і різниця у рості починається у віці старше від 30 років і вже у 40-річному насадженні різниця між середніми висотою та діаметром відповідно може становити 3,5 м і 5,5 см. Як за літературними даними, так і за нашими дослідженнями встановлено, що кедр атласький краще зростає у мішаному насадженні (Brunetti et al., 2001; Krüssmann, 1983).

У дібровних типах лісорослинних умов кедр атласький на Закарпатті перевершує таксаційні показники аборигенних деревних порід. За результатами отриманих лісівничо-таксаційних показників, у розрізі кожної зростаючої породи на ділянці, мішаних лісових культур (8Кда1Яц1См+Клг+Лпд), можна стверджувати, що 
кедр атласький характеризується кращими показниками розвитку. Запас досліджуваного деревостану в 40-річному віці становить $293 \mathrm{~m}^{3} /$ га, а середній приріст за запасом - відповідно 7,1 м³/га рік. Цю закономірність добре відображено на рис. 5.
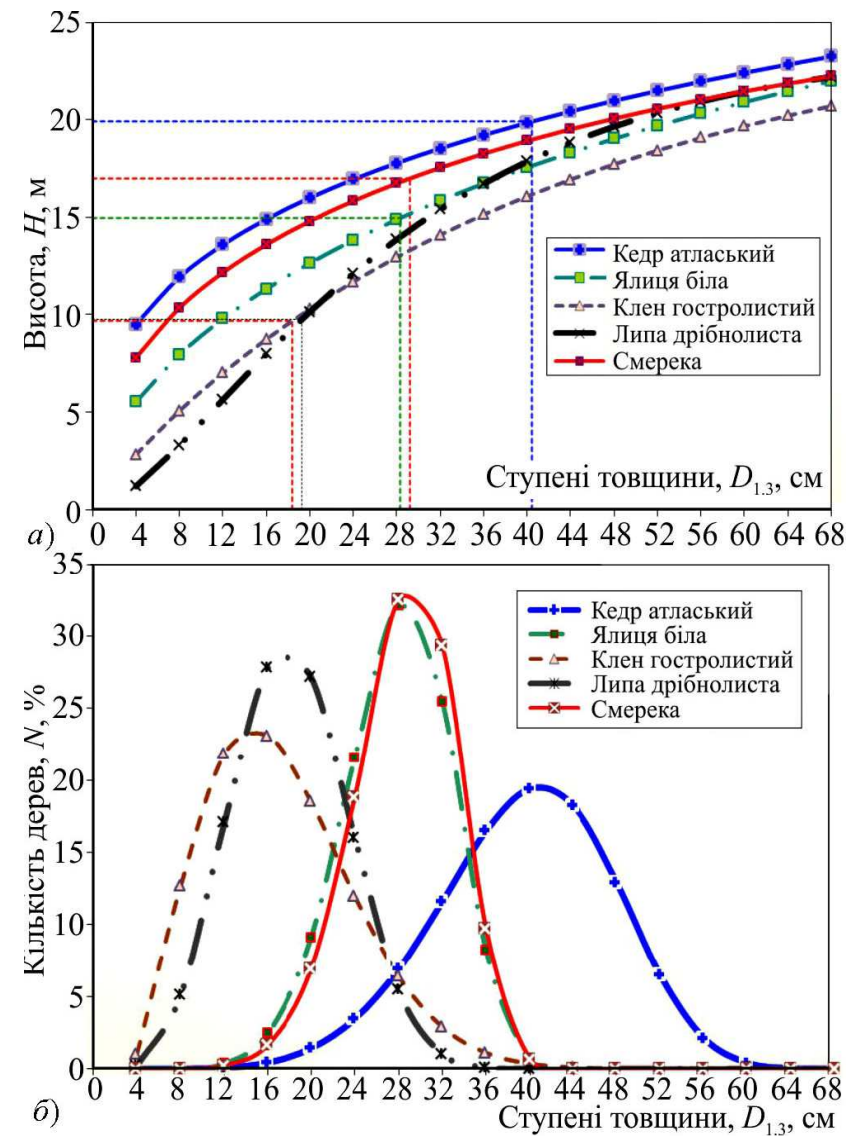

Рис. 5. Залежність росту дерев за висотою від діаметра (a) та диференціація дерев за діаметром (б)

За середнього діаметра кедра атласького 40,5 см, середня висота становить майже 20 м, що на 3-5 м є вищим за середні висоти ялиці білої та смереки. Диференціація дерев за діаметром свідчить про значний ріст, де різниця у середніх його величинах становить близько 10 см. Розмах варіації за діаметром для кедра атласького становить майже $50 \mathrm{~cm}$, а для ялиці білої та смереки - всього 30 см.

Висновки. Проведені експериментальні дослідження росту і розвитку кедра атласького в умовах Закарпаття дають змогу констатувати таке:

1. 3 трьох видів кедра (атласького, гімалайського і ліванського), які проходили виробничі випробування понад 50 років у Закарпатті, найбільш перспективним 3 лісівничого погляду виявився кедр атласький. Введення до складу мішаних культур рослин цього виду кедра дає змогу збільшити біорізноманітність та стійкість проти зміни клімату і отримати високоякісну цінну товарну хвойну деревину у віці стиглості.

2. Оптимальними умовами для культивування кедра атласького в лісових культурах є свіжі й вологі грудові типи лісорослинних умов $\left(\mathrm{D}_{2-3}\right)$ у передгірській частині Закарпаття до висоти 600 м н.р.м.

3. За своїми лісівничо-таксаційними показниками у цих лісорослинних умовах кедр атлайський має кращі показники росту та розвитку від аборигенних порід.

4. Кедр атласький в умовах Закарпаття краще зростає в мішаному насадженні. Порівняльна оцінка росту і розвитку чистих насаджень кедра атласького та мішаних 3 перевагою у складі інтродуцента свідчить, що до 20 років ця порода характеризується відносно повільним ростом як за висотою, так і за діаметром. Різниця у рості чистих та мішаних насаджень починається у віці старше від 30 років і вже у 40 років може становити 3,5 м між середніми висотами та 5,5 cм - між середніми діаметрами.

5. У досліджених умовах дерева кедра атласького регулярно і рясно плодоносять і поновлюються природним шляхом.

\section{Перелік використаних джерел}

Bariteau, M., \& Vauthier, D. (2011). Main results from the French cedar comparative field test network. In: Status of the Experimental Network of Mediterranean Forest Genetic Resources, (pp. 61-64). CRA SEL, Arezzo and FAO - Silva Mediterranea. Rome, Italy.

Brunetti, M., De Capua, E. L., Macchioni, N., \& Monachello, S. (2001). Natural durability, physical and mechanical properties of Atlas cedar (Cedrus atlantica Manetti) wood from Southern Italy. Ann. For. Sci. 58, 607-613. https://doi.org/10.1051/forest:2001148

Courbet, F., Lagacherie, M., Marty, P., Ladier, J., et al. (2012). Atlas cedar and climate change in France: assessment and recommendations INRA, $32 \mathrm{p}$.

Dörken, V. M., \& Stützel, Th. (2009). The adaptive value of shoot differentiation in deciduous trees and its evolutionary relevance. Bol. Soc. Argent. Bot., 44(3-4), 421-439.

Fodor, S. S. (1956). Dendroflora Zakarpatia i puti ee obogashheniia. Uzhhorod: Carpathians, 160 p. [In Russian].

Gadow, K. V. (2001). Waldwachstum. Fakultät für Forstwissenschaften und Waldökologie Georg-August-Universität Göttingen, 212 p.

Gorshenin, N. M., \& Buteiko, A. I. (1962). Opredelenie tipov uslovii mestoproizrastaniia. Lviv: LGU, 166 p. [In Russian].

Guz, N. M., Ivaniuk, A. P., \& Fennich, T. V. (2010). Kedr atlasskii v lesnykh kulturakh Zakarpatia. Plodovodstvo, semenovodstvo, introduktciia drevesnykh rastenii: Materials of the XIII International Scientific Conference, (pp. 42-44). Krasnoyarsk: SibGTU. [In Russian].

Herushynskyi, Z. Yu. (1996). Typolohiia lisiv Ukrainskykh Karpat. Lviv: Piramida, 208 p. [In Ukrainian].

Hnidenko, V. I. (1968). Introduktsiia novykh derev ta chaharnykiv: Naukovyi zvit Karpatskoi LNDS, 52 p. [In Ukrainian].

Hordiienko, M. I., Huz, M. M., Debryniuk, Yu. M., \& Maurer, V. M. (2005). Lisovi kultury. Lviv: Kamula, 608 p. [In Ukrainian].

Huber, G., \& Storz, C. (2014). Zedern und Riesenlebensbaum welche Herkünfte sind bei uns geeignet? LWF Wissen, 74, 63-71.

Kaplunovskyi, P. S., \& Fennych, V. S. (1998). Vdoskonalyty nasinnytstvo osnovnykh aboryhennykh ta introdukovanykh derevnykh porid na osnovi metodiv populiatsiinoi ta pliusovoi selektsii: Naukovyi zvit Karpatskoi LNDS, 68 p. [In Ukrainian].

Krüssmann, G. (1983). Handbuch der Nadelgehölze. (2nd ed.). Berlin \& Hamburg: Verlag Paul Parey.

Kuznetcov, S. I. (1984). Osnovy introduktcii i kultury khvoinykh drevnego sredizemnomoria na Ukraine $i v$ drugikh raionakh iuga SSSR. Kyiv: Scientific thought, 124 p. [In Russian].

Loginov, V. B. (1988). Introduktcionnaia optimizatciia lesnykh kulturotcenozov. Kyiv: Scientific thought, 164 p. [In Russian].

Muhidin, Š. (2019). Kurzportrait Atlaszeder (Cedrus atlantica (Endl.) Manetti ex Carrière). Retrieved from: http://waldwissen.net

Mundry, I. (2000). Morphologische und morphogenetische Untersuchungen zur Evolution der Gymnospermen. Biblioth. Bot., 152, 1-90.

Pretzsch, H. (2001). Modellierung des Waldwachstums. Parey Buchverlag Berlin, $341 \mathrm{p}$.

Smagliuk, K. K. (1974). Introdukovani khvoini lisoutvoriuvachi. Uzhhorod: Carpathians, 110 p. [In Ukrainian].

Tokar, O. Ye., Kozel, A. M., Korol, M. M., \& Tcuniak, A. M. (2016). Metodi otrimannia parametriv matematichnikh modelei dinamiki derevostaniv. Scientific Bulletin of UNFU, 26(3), 368-373. [In Ukrainian]. https://doi.org/10.15421/40260360

Yatsyk, R. M., Brodovych, R. I., \& Havrusevych, A. M. (1997). Problemy vidnovlennia ta rozvedennia lisiv $v$ Karpatskomu rehioni Ukrainy $i$ prylehlykh terytorii. Ivano-Frankivsk: Hirlis, 46 p. [In Ukrainian]. 
Yatsyk, R. M., Stupar, V. I., Fennych, V. S., \& Kaplunovskyi, P. S. (1999). Introduktsiia lisovykh derevnykh vydiv u Karpatakh. Scientific Bulletin of UkrSFU, 9(9), 27-34. [In Ukrainian].
Zaiachuk, V. Ya. (2003). Dendrolohiia. Khvoini. Lviv: Kamula, 128 p. [In Ukrainian].

M. M. Huz ${ }^{1}$, A. P. Ivaniuk1, M. M. Korol' ${ }^{1}$, T. V. Fennuch ${ }^{2}$

${ }^{1}$ Ukrainian National Forestry University, Lviv, Ukraine

${ }^{2}$ Regional branch "Lviv railway", Lviv, Ukraine

\section{SOME PECULIARITIES OF ATLAS CEDAR (CEDRUS ATLANTICA (ENDL.) MANETTI EX CARRIÈRE) GROWTH IN FOREST PLANTATIONS OF TRANSCARPATHIA}

The paper presents a brief description of Atlas cedar. The history of creation of alien plantations on the territory of the Mukachevo Forestry and Hunting Farm SOE of the State Forest Fund is explored. The optimal conditions for cultivating Atlas cedar in forest plantations are found to be fresh and wet oak-hornbeam forest vegetation types $\left(D_{2-3}\right)$ in the foothill part of Transcarpathia to a height of $600 \mathrm{~m}$ above sea level. The indices of productivity of the investigated species plantations are determined. Atlas cedar is revealed to exceed the valuation features of native tree species in the oak grove forest conditions in Transcarpathia. The comparative estimation of forestry and valuation features in the section of each growing species on the investigated area shows that Atlas cedar is characterized by the best development indicators. The stock of the investigated tree stand, where the composition is $8 \mathrm{Kda} 1 \mathrm{Yats} 1 \mathrm{Sm}+\mathrm{Klh}+\mathrm{Lpd}$, at the age of 40 is $293 \mathrm{~m}^{3} / \mathrm{ha}$ and the average stock increase is respectively $7.1 \mathrm{~m}^{3} / \mathrm{ha}$ per year. When the average diameter of Atlas cedar is $40.5 \mathrm{~cm}$, the average height is almost $20 \mathrm{~m}$, which is $3-5 \mathrm{~m}$ is higher than the average height of Silver fir and European spruce. Differentiation of trees by their diameter indicates a significant growth, where the difference in its average values is about $10 \mathrm{~cm}$. Ranging in diameter for Atlas cedar is about $50 \mathrm{~cm}$, and for Silver fir and European spruce is only 30 $\mathrm{cm}$. Mixed plantings of Atlas cedar are found to be significantly higher concerning the average height and diameter compared with pure tree stands in the same soil and climatic conditions of Transcarpathia. Changes in the processes of occurrence of natural regeneration in the alien plantings are investigated, and the main factors influencing this process are defined as well. The research conducted testifies that Atlas cedar in the conditions of fresh and wet oak-hornbeam forest vegetation types of Transcarpathia reached the highest level of acclimatization - naturalization, which confirms the ability of the species to a natural regeneration. The initiated research is aimed at establishing prospects for the use of the species in the forest cultivated production of the region, determining the degree of naturalization of the species and the aggressiveness of its behavior regarding the autochthonous tree species in indigenous forest types.

Keywords: Atlas cedar; growth; alien; natural regeneration; forest plantations. 